\title{
Ground motion simulations of the $S W$ Iberia margin: rupture directivity and earth structure effects
}

\section{Bezzeghoud, J. F. Borges \& B. Caldeira}

\section{Natural Hazards}

Journal of the International Society for the Prevention and Mitigation of Natural Hazards

ISSN 0921-030X

Nat Hazards

DOI 10.1007/s11069-011-9925-2

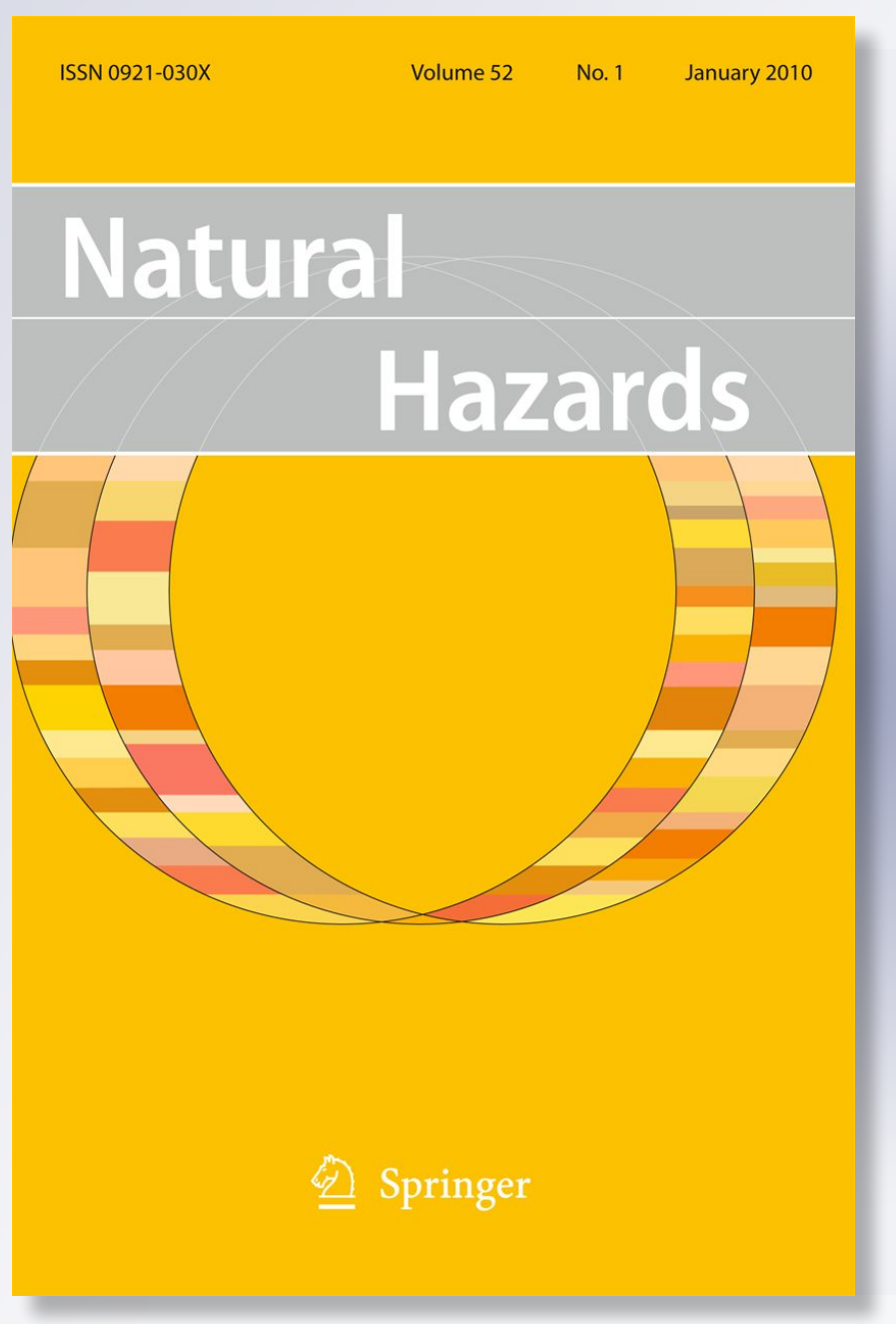

留 Springer 
Your article is protected by copyright and all rights are held exclusively by Springer Science+Business Media B.V.. This e-offprint is for personal use only and shall not be selfarchived in electronic repositories. If you wish to self-archive your work, please use the accepted author's version for posting to your own website or your institution's repository. You may further deposit the accepted author's version on a funder's repository at a funder's request, provided it is not made publicly available until 12 months after publication. 


\title{
Ground motion simulations of the SW Iberia margin: rupture directivity and earth structure effects
}

\author{
M. Bezzeghoud · J. F. Borges $\cdot$ B. Caldeira
}

Received: 25 June 2010/ Accepted: 5 August 2011

(C) Springer Science+Business Media B.V. 2011

\begin{abstract}
In this study, we focus on the region between Gorringe Bank and the Horseshoe Fault located in the SW Iberia margin, which is believed to be the site of the great 1755 earthquake. We model ground motions using an extended source located near the Horseshoe scarp to generate synthetic waveforms using a wave propagation code, based on the finite-difference method. We compare the simulated waveforms, for the Algarve Basin and the Lower Tagus Valley Basin (Portugal), using a 3-D velocity model down to the Moho discontinuity with a simple 1-D layered model. The radiated wave field is very sensitive to the velocity model and a small number of source parameters, in particular, the rupture directivity. The rupture directivity, the strike direction and the fault dimensions are critical to the azimuthal distribution of the maximum amplitude oscillations. We show that the use of a stratified 1-D model is inappropriate in SW Iberia, where sources are located in the oceanic domain and receivers in the continental domain. The crustal structure varies dramatically along the ray paths, with large-scale heterogeneities of low or high velocities. Moreover, combined with the geometric limitations inherent to the region, a strong tradeoff between several parameters is often observed; this is particularly critical when studying moderate magnitude earthquakes $(M<6)$, which constitute the bulk of the seismic catalogue in SW Iberia.
\end{abstract}

Keywords Seismicity · Ground motion - Seismic source · Rupture directivity · Earth structure $\cdot$ Iberia margin

\section{Introduction}

The interaction between Iberia and Nubia results in a complex region located in the western part of the Eurasia-Nubia plate boundary (Fig. 1). This region corresponds to the transition from an oceanic boundary (between the Azores and the Gorringe Bank) to a continental boundary, where Iberia and Nubia meet (Borges et al. 2001; Buforn et al. 2004;

M. Bezzeghoud $(\bowtie) \cdot$ J. F. Borges · B. Caldeira

Geophysical Centre of Évora and Physics Department, ECT, University of Évora, Évora, Portugal e-mail: mourad@uevora.pt 


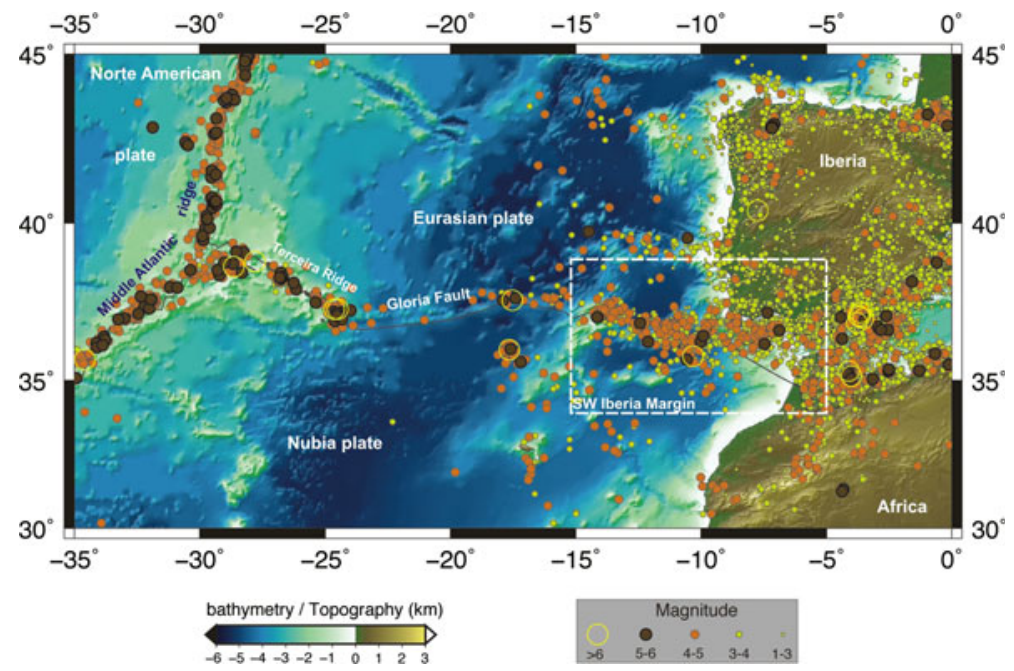

Fig. 1 Seismicity and the main tectonic features in the western part of the Eurasia-Nubia plate boundary for the period 1973-2010 (NEIC Data File). The tectonic boundaries are taken from Bird (2003), and the bathymetric lines are taken from the digital bathymetric data set ETOPO2 (U.S. Department of Commerce, NOAA/NGDC, 2001)

Grandin et al. 2007a). The current tectonic regime at the boundary of the Nubian and Eurasian plates varies with longitude (Fig. 1) as a result of the rotation of Nubia, with respect to Eurasia, around a Euler pole located offshore Morocco, close to $20^{\circ} \mathrm{N}, 20^{\circ} \mathrm{W}$ (Argus et al. 1989; DeMets et al. 1994). This boundary can be divided into five sections (Bezzeghoud et al. 2008). To the west, between the Nubia-Eurasia-North America triple junction $\left(35^{\circ} \mathrm{W}\right)$ on the eastern end of the Terceira Ridge $\left(24^{\circ} \mathrm{N}\right)$, the regime is transtensional, with an extension rate of $4.2 \mathrm{~mm}$ year $^{-1}$ (Borges et al. 2007, 2008; Bezzeghoud et al. 2008), and is responsible for the active volcanism found in the Azores archipelago. In the central section, the relative motion of the two plates seems to be accommodated by a single right-lateral fault, the Gloria Fault, although significant seismic activity is observed in a broad region off the fault (Lynnes and Ruff 1985). East of $16^{\circ} \mathrm{W}$, the bathymetric continuation of the Gloria Fault cannot be followed, and the definition of the boundary is less clear. A transpressive tectonic regime dominates, with a very low convergence rate of $4 \mathrm{~mm} \mathrm{year}^{-1}$ (Argus et al. 1989; McClusky et al. 2003) trending NW-NNW, consistent with the observed maximum horizontal stress direction (Ribeiro et al. 1996; Borges et al. 2001; Stich et al. 2003; Carrilho et al. 2004). Deformation is distributed over an increasingly large area that reaches a N-S width of $300 \mathrm{~km}$ near the continental margin of Iberia (Chen and Grimison 1989). In this section, the seismicity is scattered, with most events concentrated along a $100-\mathrm{km}$-wide band that trends ESE-WNW from $16^{\circ} \mathrm{W}$ to $7^{\circ} \mathrm{W}$ (Fig. 2). A progressive shift of focal mechanisms, from strike-slip mechanisms in the west to predominant reverse faulting in the east, has also been reported (Buforn et al. 1988, 2004; Borges et al. 2001) and can be interpreted as an increasing plunge of the minimum compression axis. In the Gulf of Cadiz, the seismicity is denser to the north, around the Guadalquivir Bank (Fig. 2). East of the Strait of Gibraltar, in the Alboran domain and the Betic-Rif Arc, both seismicity (Calvert et al. 2000) and GPS data (Fadil et al. 2006) suggest that active deformation is spread over several hundred kilometres. In this study, we focus on the central section, which is believed to be the site of the great 1755 earthquake. 


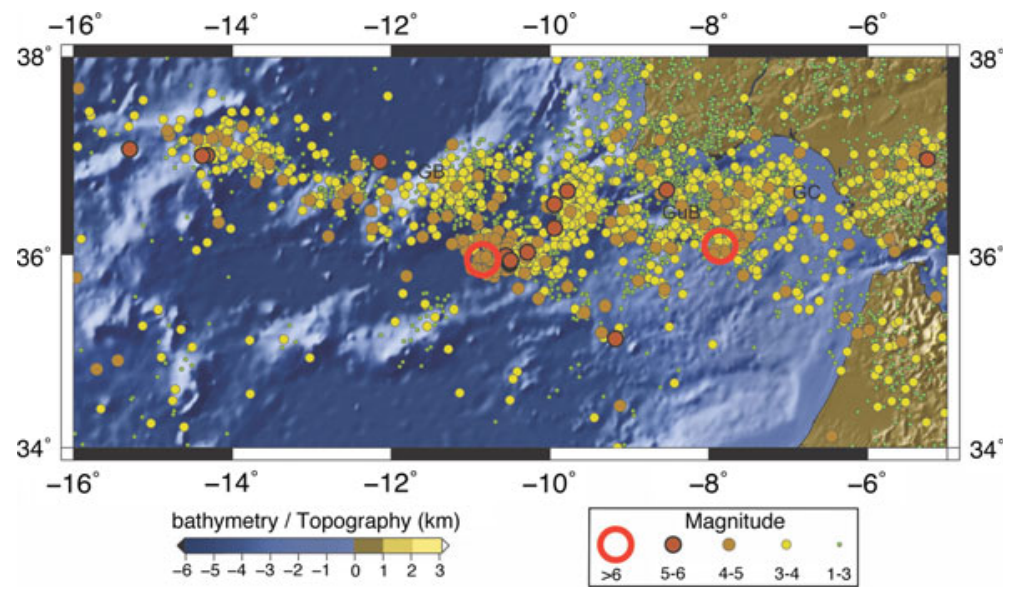

Fig. 2 Seismicity provided by the Institute of Meteorology (IM, Portugal) in the southwestern Iberian margin for the period 1961-2010. GB: Gorringe Bank; GuB: Guadalquivir Bank; GC; Gulf of Cadiz

We concentrate our analysis on ground motion modelling using an extended source located near the Horseshoe structure to generate synthetic waveforms using a wave propagation code based on the finite-difference method. We compare simulated waveforms, for the Algarve Basin and the Lower Tagus Valley Basin (Portugal), using a 3-D velocity model down to the Moho discontinuity with a simple 1-D layered model. We confirm that the radiated wave field is very sensitive to the velocity model and the rupture directivity. The rupture directivity, strike direction and fault dimensions are the critical factors for correctly modelling the azimuthal distribution of maximum amplitude oscillations.

\section{Seismo-tectonic setting}

The region east of $16^{\circ} \mathrm{W}$ is dominated by a transpressive tectonic regime, with a very low convergence rate between 4.0 and $5.5 \mathrm{~mm}$ year $^{-1}$ (Argus et al. 1989; Buforn et al. 2004; Bezzeghoud et al. 2008) trending NW to NNW, consistent with the observed maximum horizontal stress direction (Ribeiro et al. 1996; Borges et al. 2001; Jiménez-Munt et al. 2001). Deformation may be distributed over a large area (Chen and Grimison 1989) as a result of the complex boundary conditions imposed on the Iberian plate (Andeweg et al. 1999; Jiménez-Munt et al. 2001). As a result of the complex tectonic history of the area, the western Iberian margin and its onshore extension are made up of a succession of uplifted blocks and areas of relative subsidence (Alves et al. 2003). East of $16^{\circ} \mathrm{W}$, the absence of a continuous bathymetric trace along the Africa-Iberia boundary does not allow plate boundaries to be defined with certainty. According the Wilson cycle, passive margins (Atlantic-type Ocean) can be converted to active margins (Pacific-type Ocean) (Wilson 1966). A synthesis of several seismotectonic studies (i.e. Udías et al. 1976; Udias and Buforn 1994; Ribeiro et al. 1996; Borges et al. 2001; Ribeiro 2002) shows that the West Iberia margin is in state of transition from passive to active (Ribeiro 2002). However, the mechanism for converting passive margins into active margins is not still well understood.

In this region, we do not see a clear delineation between plates, and deformation is distributed over an increasingly large area that can reach a N-S width of $300 \mathrm{~km}$ near the 
continental margin of Iberia. The seismicity is scattered, but most events are concentrated along a $100-\mathrm{km}$-wide band, trending ESE-WNW from $16^{\circ} \mathrm{W}$ to $9^{\circ} \mathrm{W}$. In this area, a series of topographic structures trend WSW-ENE (Zitellini et al. 2009). The Horseshoe scarp and the Marquês de Pombal scarp (Fig. 3), parallel to the St. Vicente Canyon, have experienced deformation since at least the Miocene (Gràcia et al. 2003) and are located above the transitional domain of the ocean-continent transition (OCT). This scenario is supported by the occurrence of unusually large oceanic earthquakes within the area of scattered seismicity, such as the 1969 earthquake $\left(M_{w}=7.8\right)$ and the 1755 Lisbon earthquake $\left(M_{w}=8.5-8.7\right.$, Table 1, Fig. 3).

In the last 5 years, there has been an increase in seismic activity in the area between Gorringe Bank and the Horseshoe Fault (Fig. 2). The largest recorded earthquake occurred offshore in $1969\left(M_{w}=7.8\right)$, but since then, only two earthquakes have reached a magnitude greater than 5.5 (Table 1). These earthquakes all struck the region located between the Horseshoe Abyssal Plain and Cape St. Vicente where seismic activity decreases towards the coast. In this area, a series of topographic structures trending WSW-ENE exhibit clear seismic activity (Fig. 3).

Most major submarine canyons are aligned with NE-SW-trending faults on land, suggesting tectonic control over a broad area (Fig. 3). These faults were reactivated as reverse faults during Miocene compression, and historical records of large earthquakes show that they are still active today (Fig. 3). The Nazaré Canyon corresponds to the Nazaré Fault, which has been active since the middle Cretaceous. It may be responsible for earthquake activity in the Batalha-Alcobaça region, with the latest event dating to $1890(M=4.5)$. The Lower Tagus Fault Zone, whose seismo-tectonic interpretation is still under debate, might be extended by the Lisbon Canyon. This fault zone was active in $1344(M=6.0)$, $1531(M=7.1)$ and $1909(M=6.0)$ (Moreira 1982; Teves-Costa et al. 1999). The system may also have been activated during the 1755 Lisbon earthquake (Vilanova 2003), suggesting a recurrence interval of 200 years. The source of the 1858 Setubal earthquake $(M=7.1)$ may be a blind thrust fault, trending NNE-SSW, located below the Setubal Canyon, in the Sado Valley (Ribeiro 2002). The St. Vicente Canyon is aligned with the Messejana Fault, a deep fault of lithospheric dimensions, showing 1-2 km of vertical throw in the upper crust on seismic profiles (Matias 1996), but no clear seismic activity.

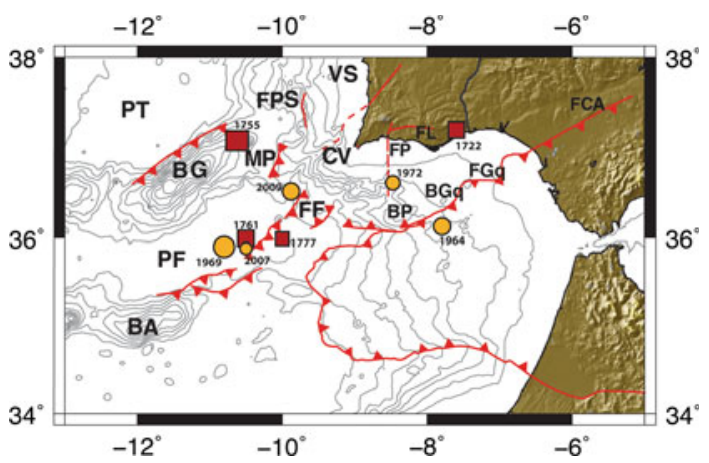

Fig. 3 Significant earthquakes (see Table 1) and major active faults (adapted from Zitellini et al. 2009) in the southwestern Iberian margin. PT = Tejo plain; FPS: Pereira de Sousa Fault; PF = Horseshoe plain; $\mathrm{FF}=$ Horseshoe Fault; BA = Ampere bank; BGq = Guadalquivir bank; VS = Vale do Sado; MP = Marquês de Pombal Fault; $\mathrm{BG}=$ Gorringe bank; $\mathrm{FGq}=$ Guadalquivir Fault; $\mathrm{FM}=$ Messejana Fault; $\mathrm{FL}=$ Loulé Fault; FP = Portimão Fault; CV = St. Vicente Cape; FCA = Cadiz-Alicante Fault 
Table 1 Significant earthquakes $(M \geq 5.5)$ in the southwestern part of the Iberian margin

\begin{tabular}{llllll}
\hline $\begin{array}{l}\text { Date }(\mathrm{dd} / \mathrm{mm} / \\
\text { year) }\end{array}$ & Latitude & Longitude & $M$ & Location & Ref. \\
\hline $27 / 12 / 1722$ & $37.20 \mathrm{~N}$ & $07.6 \mathrm{~W}$ & $M_{w} 6.5$ & Tavira (Algarve) & Baptista et al. (2007) \\
$01 / 11 / 1755$ & $36.94 \mathrm{~N}$ & $11.45 \mathrm{~W}$ & $M_{w} 8.5-8.7$ & SW S. Vicente Cape & Grandin et al. (2007b) \\
$31 / 03 / 1761$ & $34.50 \mathrm{~N}$ & $13.00 \mathrm{~W}$ & $M 7.5\left(M_{t} 8.0\right)$ & SW S. Vicente Cape & Baptista et al. (2006) \\
$12 / 01 / 1856$ & $37.10 \mathrm{~N}$ & $08.0 \mathrm{~W}$ & $M 6.0$ & Loulé (Algarve) & LNEC (1986) \\
$12 / 04 / 1777$ & $36.00 \mathrm{~N}$ & $10.00 \mathrm{~W}$ & $M_{7} 7.0$ & SW S. Vicente Cape & LNEC (1986) \\
$05 / 12 / 1960$ & $35.60 \mathrm{~N}$ & $06.50 \mathrm{~W}$ & $M_{w} 6.2$ & SW S. Vicente Cape & Buforn et al. (1988) \\
$15 / 03 / 1964$ & $36.10 \mathrm{~N}$ & $07.80 \mathrm{~W}$ & $M_{s} 6.1$ & SE S. Vicente Cape & Buforn et al. (1988) \\
$28 / 02 / 1969$ & $35.90 \mathrm{~N}$ & $10.80 \mathrm{~W}$ & $M_{w} 7.8$ & SW S. Vicente Cape & Grandin et al. (2007b) \\
$05 / 05 / 1969$ & $36.00 \mathrm{~N}$ & $10.40 \mathrm{~W}$ & $M_{w} 5.5$ & SW S. Vicente Cape & Buforn et al. (1988) \\
$12 / 02 / 2007$ & $35.80 \mathrm{~N}$ & $10.31 \mathrm{~W}$ & $M_{w} 5.9$ & SW S. Vicente Cape & Buforn et al. (2007) \\
$17 / 12 / 2009$ & $36.46 \mathrm{~N}$ & $09.90 \mathrm{~W}$ & $M_{w} 5.6$ & SW S. Vicente Cape & USGS \\
\hline
\end{tabular}

$M_{w}, M_{t}, M_{s}$ and $M$ represent, respectively, moment, tsunami, surface-wave and unified magnitude

The Portimão Fault, dating to the Permian, shows seismic activity and can be followed along the Portimão Canyon. The Loulé Fault may accommodate a significant part of the shortening across the Algarve basin, due to the presence of halokinetic structures in its footwall, and may have exhibited recent seismic activity in $1587(M=5.5)$ and 1856 $(M=5.5)$ (Moreira 1984; Terrinha 1998). The source of the tsunamigenic 1722 Tavira earthquake $\left(M_{w}=6.5\right.$, Baptista et al. 2007; Chester and Chester 2010) may be located offshore the southern Portuguese coast, possibly near the Guadalquivir bank area. The 1761 earthquake $\left(M=7.5 ; M_{t}=8.0\right)$ also occurred offshore, generating a large tsunami, but its location is extremely uncertain (Baptista et al. 2006). This is also the case for the largest earthquake ever reported in Europe, which occurred in this region in 1755 ( $M_{w}=8.5-8.7$, Grandin et al. 2007b), accompanied by a massive tsunami. For this event, different seismogenic origins are currently supported by various authors (e.g. Zitellini et al. 2001; Gutscher et al. 2002; Grandin et al. 2007b; Barkan et al. 2009).

\section{Ground motion simulations and earthquake source}

The velocity model of the crust used in this study incorporates the major seismogenic centres observed offshore SW Iberia, between Gorringe Bank and the Betic Cordillera in the region lying between latitudes $35.2^{\circ} \mathrm{N}$ and $39.7^{\circ} \mathrm{N}$ and between longitudes $11.8^{\circ} \mathrm{W}$ and $6.1^{\circ} \mathrm{W}$. The crust is stratified and is made of a superposition of a finite number of layers, with varying depths and thicknesses. Only the depth of each interface between layers must be specified at given points; then, a Delaunay triangulation can be applied to fill the spaces between these points (Watson 1982). A layer can thus taper off and reach zero thickness, if necessary, which is convenient for modelling sedimentary basins or the OCT. To account for their complex geometries and high variations of thickness/depth, these regions only require a denser network of data points. We also assumed that both continental and oceanic crust could be described with the same layers, by coupling layers that have similar wave propagation velocities and densities in the two domains. The links between coupled layers are assessed based on the seismic profiles. However, their resolutions are often insufficient to locate small lateral velocity discontinuities, and we thus focus on large wavelength 
variations of major intra-crustal layer thicknesses. In this model, the purely oceanic crust is separated from the continental crust by a transitional domain, probably made up of thinned, highly faulted or intruded continental crust. The classification for continental crust layers uses nine different layers with distinct physical identified properties. These overlie the upper mantle, which is modelled as a half-space, with a uniform P-velocity of $8.1 \mathrm{~km} \mathrm{~s}^{-1}$ and a $\mathrm{Vp} / \mathrm{Vs}$ ratio of 1.74 to deduce $\mathrm{S}$-wave velocities from $\mathrm{P}$-wave velocities (Grandin et al. 2007a). Densities were set based on the experimental measures of density for a set of crustal rocks. The complete SWIB2006 velocity model is discussed in Grandin et al. (2007a) and posted on the webpage http://evunix.uevora.pt/ jborges/3DSEISM/ get_SWIBmod.html; it is freely available to the public.

The 1 November 1755 earthquake was the strongest earthquake ever reported in Europe and was extremely destructive (Portugal: Pereira de Sousa 1919; Spain: Martínez-Solares et al. 1979; Morocco: Levret 1991) — the shock was felt even in Northern Germany, the Azores and the Cape Verde Islands (Reid 1914). The large size of the earthquake is further evidenced by the observations of seiches in southern England and Holland and as far as Finland (Reid 1914). The large tsunami waves generated by the earthquake also caused extensive damage along the coasts of Portugal, southern Spain and Morocco and were even detected in the Lesser Antilles and southwestern England. Extensive geological evidence of tsunami deposits associated with the 1755 earthquake has been reported in Europe (e.g. Andrade 1992; Dawson et al. 1995; Abrantes et al. 2005; Scheffers and Kelletat 2005). The problem of epicentral location has been addressed by various early studies (Reid 1914; Pereira de Sousa 1919), and since the beginning of the instrumental period, a consensus has attributed the origin of the earthquake to a structure located between the Gorringe Bank and the Coral Patch Ridge (Machado 1966; Moreira 1985; Johnston 1996; Grandin et al. 2007b; Barkan et al. 2009). In the most recent hypothesis, Grandin et al. (2007b) tested, by forward modelling, three published sources for the 1755 earthquake that can be considered as end-members of the set of proposed offshore seismic sources (Johnston 1996; Zitellini et al. 2001; Terrinha et al. 2003; Gutscher et al. 2002; Gutscher et al. 2006; Thiebot and Gutscher 2006). Following the results of these tests, Grandin et al. (2007b) concluded that a fault located below Gorringe Bank, with a rupture directed towards the SW, reproduces the overall pattern of macroseismic observations better than a fault aligned along the Marquês de Pombal-Pereira de Sousa Fault zone or a subduction-related thrust fault in the Gulf of Cádiz. Except for Grandin et al. (2007b), all seismic modellings of the 1755 Lisbon earthquake performed by various authors (Mendes-Victor et al. 1999; Baptista et al. 2003; Gutscher et al. 2006) suffer limitations, because they do not take into account physical considerations related to the complexity and directivity of the seismic source on one hand or the propagation medium on the other hand (Grandin et al. 2007a, b).

To model the propagation of seismic waves in a 3-D medium, we used the code E3D, an explicit 2-D/3-D elastic finite-difference wave propagation code (Larsen and Schultz 1995) based on the work of Madariaga (1976). The method, computational issues related to the finite-difference scheme and source implementation are given in detail in Grandin et al. (2007a, b). The method has been successfully applied by a large number of authors to generate synthetic seismograms (e.g. Olsen and Archuleta 1996; Larsen et al. 1997; Pitarka et al. 2004; Hartzell et al. 2006; Kagawa et al. 2004; Grandin et al. 2007a, b).

For a source like that of the 1755 Lisbon earthquake $\left(M_{w}=8.5-8.7\right)$, the finiteness of the fault dimensions and of the duration of rupture cannot be ignored. Following the source implementation scheme of E3D, we model this extended source by superimposing a large number of point sources over a rectangular fault plane that has the same strike and dip as the individual subevents. The kinematics of the rupture, namely, the rupture propagation 
direction, are simulated by triggering a rupture on each subfault at the right time: a rupture can nucleate at a certain location on the fault and then propagate radially until the fault edge is reached-the rupture velocity is assumed to be constant over the fault plane. To prevent high-frequency noise from entering the radiated spectrum and to thus generate a smooth source time function, it is important that the rupture on each subfault is initiated before the rupture on the previous adjacent subfault has stopped. We chose to use a Brune signal as the elementary source time function for rupture on each subfault (Brune 1970). In the case of a finite source, the rupture velocity is fixed at $2.5 \mathrm{~km} \mathrm{~s}^{-1}$ and the grid spacing is $1 \mathrm{~km}$ (maximum frequency of $0.3 \mathrm{~Hz}$ ). We also assume a uniform seismic moment distribution over the fault plane. Thus, the slip is not uniform, due to variations in the rigidity modulus with depth in the velocity model. However, in the epicentral distance range considered here $(d>100 \mathrm{~km})$, we have verified that this condition does not induce significant differences from a uniform geometric moment distribution. Furthermore, we set the depth to the top of the fault so that co-seismic rupture does not extend beyond the seismic basement. This prevents the occurrence of super-shear rupture velocities in the shallow sedimentary cover, but assumes that sediments are not involved in significant seismic wave generation. This hypothesis is valid from a seismological point of view (Grandin et al. 2007b).

The stability of this method has already been verified by Grandin et al. (2007a, b) through a large number of simulations to evaluate the importance of the arbitrarily fixed parameters, such as the characteristic time of subevent rupture, which sets both the rise time and the duration of the rupture, the rupture velocity and the complex geometry. On the other hand, variations in the focal parameters, fault plane geometry and rupture directivity have strong effects on the resulting radiated wave field. The computational domain has a grid spacing of $1 \mathrm{~km}$ and extends to a depth of $70 \mathrm{~km}$.

\section{Rupture directivity and earth structure effects}

For this study, we compare simulated waveforms based on the source parameters given in Table 2 for a 3-D velocity model down to the Moho discontinuity versus a simple 1-D layered model (Figs. 5,6). We confirm that the radiated wave field is very sensitive to the velocity model (Figs. 4, 7) and a small number of source parameters, in particular, the rupture directivity (Fig. 8). In contrast, the computation is not very sensitive to other source parameters, such as the dip, the rake, the rupture velocity, the depth to the top of the fault or the duration and shape of the source time function. Figures 4 and 7 show that the use of a stratified 1-D model is definitively inappropriate in SW Iberia, where sources are located in the oceanic domain and receivers in the continental domain (Fig. 5); the crustal structure varies dramatically along the ray paths, with large-scale heterogeneities of low or high velocities (Fig. 6). Figure 7 shows that in the Mesozoic basin, the 3-D velocity model gives maximum velocity values that are about a factor of two and three higher than those given by the 1-D velocity model, respectively, for Faro (Algarve) and Coina (Lower Tagus Valley) profiles. Moreover, combined with the geometric limitations inherent to the region, a strong trade-off between several parameters is often observed: this is particularly critical when studying moderate magnitude earthquakes $(M<6)$, which constitute the bulk of the seismic catalogue in SW Iberia. Figure 8 shows the significance of the directivity effect, which is controlled by the rupture initiation location, for two profiles (Faro and Coina) and three rupture scenarios: directive, anti-directive and bi-lateral. For the Faro profile, the directive rupture gives the maximum velocity values; in the Mesozoic basin, they are 
Table 2 Source parameters used to compute synthetic waveforms (see text for discussion)

\begin{tabular}{|c|c|c|c|c|c|c|c|c|c|}
\hline Scenario & $\begin{array}{l}\text { Nucleation } \\
\text { point } \\
\mathrm{X} ; \mathrm{Y}(\mathrm{km})\end{array}$ & $\begin{array}{l}\text { Fault area } \\
\mathrm{L} \times \mathrm{W}\end{array}$ & $\mathrm{H}(\mathrm{km})$ & $\begin{array}{l}M_{o} \times \\
10^{22}(\mathrm{Nm})\end{array}$ & $M_{w}$ & Strike & Dip & Rake & $\operatorname{Vr}(\mathrm{km} / \mathrm{s})$ \\
\hline Directive & $53.33 ; 50$ & & & & & & & & \\
\hline Bilateral & $53.33 ; 0$ & $200 \times 80$ & 8 & 1.16 & 8.7 & 60 & 40 & 90 & 2.7 \\
\hline Anti-directive & $53.33 ;-50$ & & & & & & & & \\
\hline
\end{tabular}

$V r$ rupture velocity, $H$ depth of the top of the fault
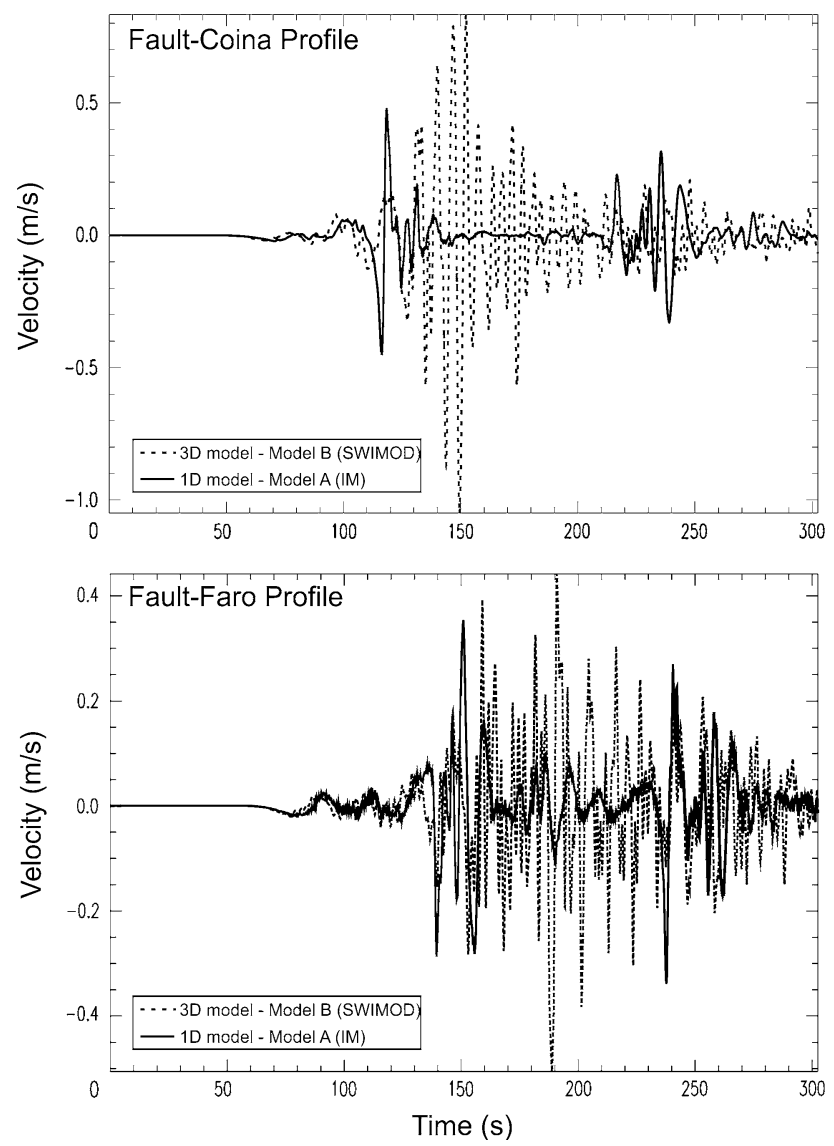

Fig. 4 Comparison between simulated waveforms obtained using a 3-D velocity model down to the Moho discontinuity and a simple 1-D layered model for the first point close to Faro city (bottom) and Coina (top) (see profiles located on Figs. 5, 6)

greater than those of the anti-directive rupture by a factor of about 6 and are greater than those of the bilateral rupture by a factor of 3.5. This shows clearly that the stronger ground motions and damage are distributed in an elongated pattern centred along the axis of the 
Fig. 5 Off shore, source location and rupture process used for the simulated waveforms determined in this study. The red star marks the epicentre, and the arrows represent the average direction and the extent of the rupture front during the related period for the directive, bi-lateral and antidirective scenarios. On land, major geological units are featured, and the two lines shown by open circles indicate the two profiles (Faro and Coina) where simulated waveforms are determined. The corresponding values are indicated at the tops of Figs. 4, 7 and 8

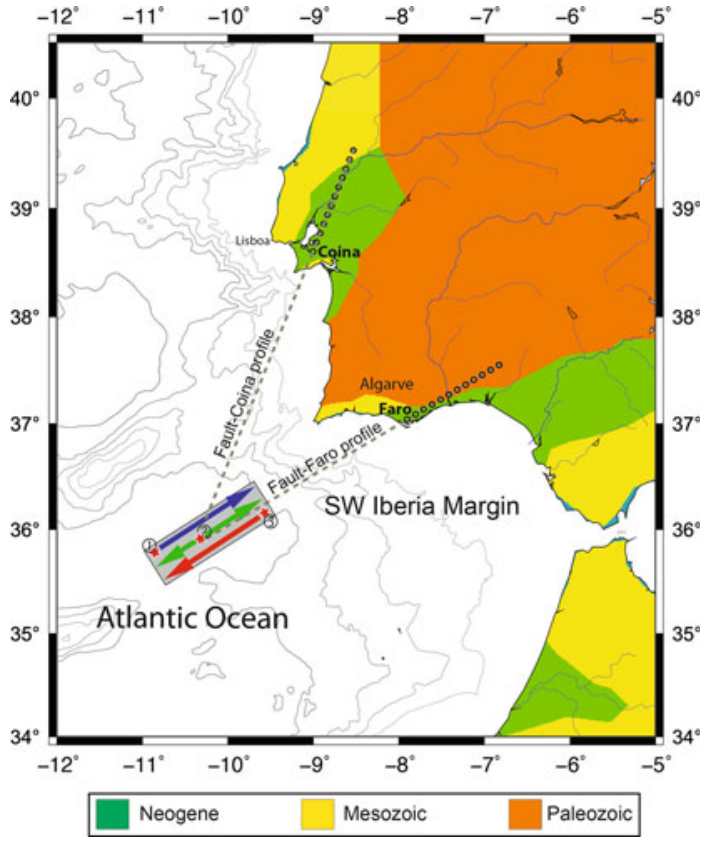

fault (Fig. 5). For the Coina profile, the directivity effect is not significant because the profile is out of the axis of the fault (Fig. 5).

The rupture directivity, velocity model, strike direction and fault dimensions are critical factors controlling the azimuthal distribution of the maximum amplitude oscillations. The radiation that issues from an extended seismic source when a rupture spreads in preferential directions can be distinguished from that emitted by a point source. This distinctive characteristic, which is known as directivity (Ben-Menahem 1961), is manifested by an increase in the frequency and amplitude of seismic waves when the rupture occurs in the direction of the seismic station and a decrease if it occurs in the opposite direction (e.g. Caldeira et al. 2009). These effects are maxima when the rupture direction is in the axis of the propagation direction and are not present when the rupture direction is perpendicular to the propagation direction.

\section{Discussion}

The results of this study clearly show that earthquake directivity is the focusing of wave energy along a fault in the direction of rupture, which means that, exclusive of local site conditions (e.g. soft soils), the stronger ground motions and related damage (for large earthquakes) will be distributed in an elongated pattern centred along the axis of the fault. The distance to the fault is not the only consideration for ground motion amplitude; the structure and the rupture directivity are also important. We confirm that the radiated seismic wave field is highly sensitive to the rupture directivity and to the Earth's structure. 


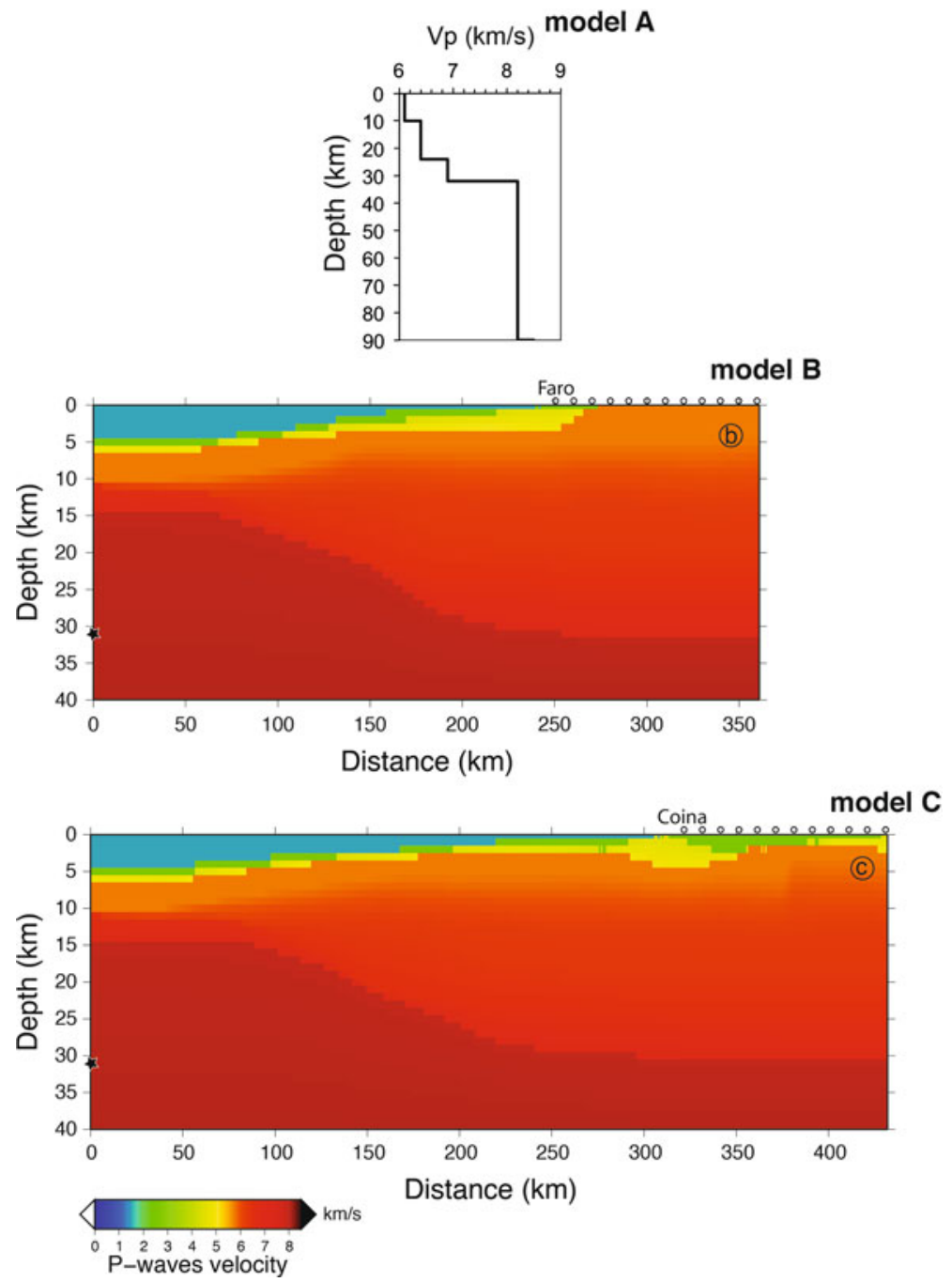

Fig. 6 P-waves velocity models. a 1-D velocity model (Institute of Meteorology, Lisbon) (Model A); Cross-section of the P-waves 3-D velocity model, with a grid spacing of $1.0 \mathrm{~km}$, which corresponds to the ocean-continent transition offshore along b Faro (Model B) and $\mathbf{c}$ Coina (Model C) profiles located in Fig. 5. For the cross-sections, we used SWIBMOD model (http://evunix.uevora.pt/ jborges/3DSEISM/get_ SWIBmod.html, Grandin et al. 2007a)

5.1 Directivity effect and importance of the earth's structure (i.e. 3-D model)

\subsubsection{Directivity effect}

When a fault ruptures unilaterally (with the epicentre at or near one extremity of the rupture), the radiated waves are stronger in one direction along the fault. The characteristics of ground shaking close to a fault rupture generally depend on whether the rupture 

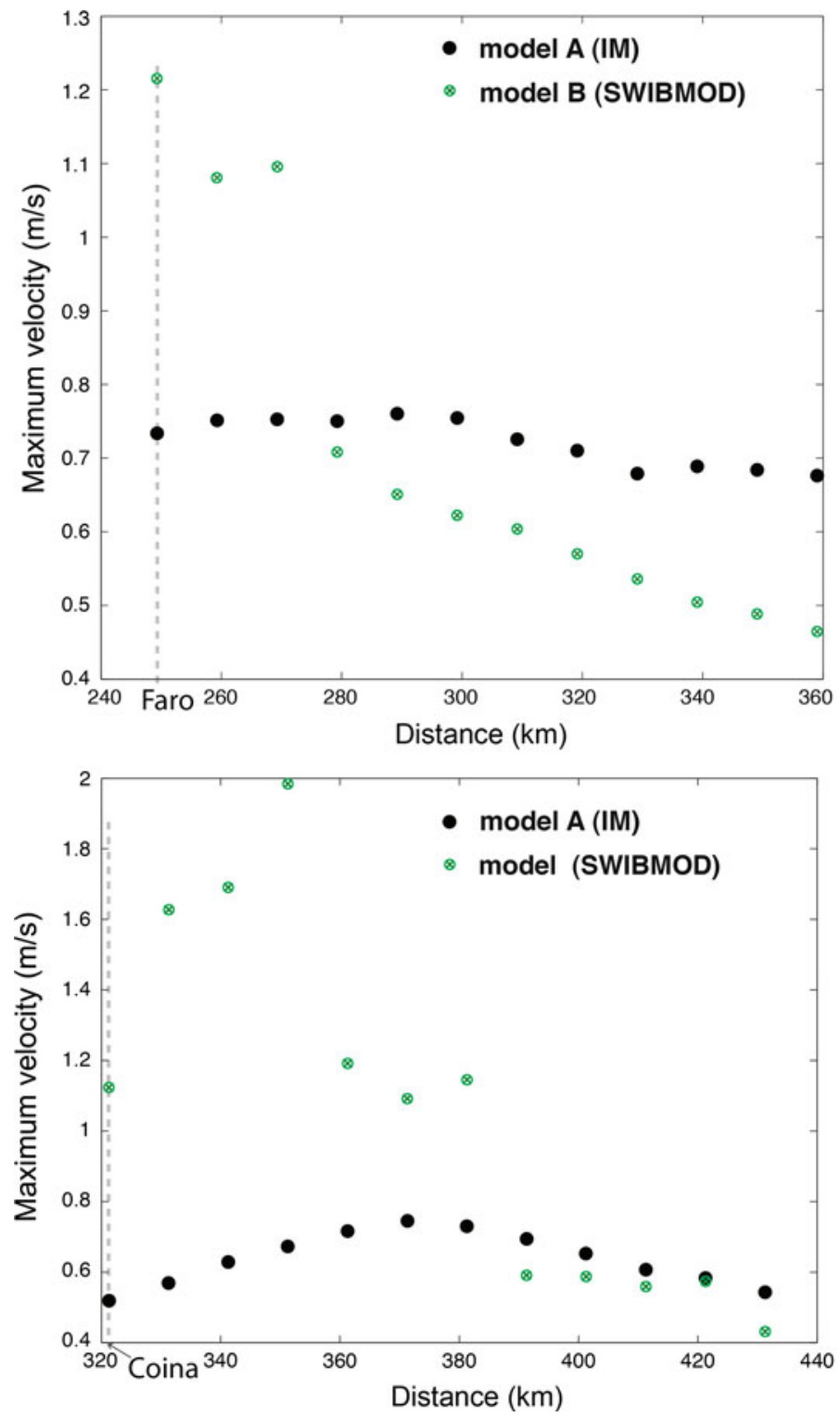

Fig. 7 Earth structure effect. Comparison between simulated maximum velocities obtained using a 3-D velocity model (Model B) down to the Moho discontinuity with a simple 1-D layered model (Model A) along the Faro (top) and Coina (bottom) profiles, represented by open circles, shown in the Figs. 5 and 6

moves towards the building site or away from it. These two cases are often referred to as forward and backward directivity conditions, respectively. In the forward directivity case, the ground motion tends to have a pulse that is often clearly apparent in the velocity time histories. The average period of such pulses, which appears to depend on magnitude, may vary from approximately $1.5 \mathrm{~s}$ for an $M_{w} 6.5$ event to more than $3 \mathrm{~s}$ for an $M_{w} 7.5$ 

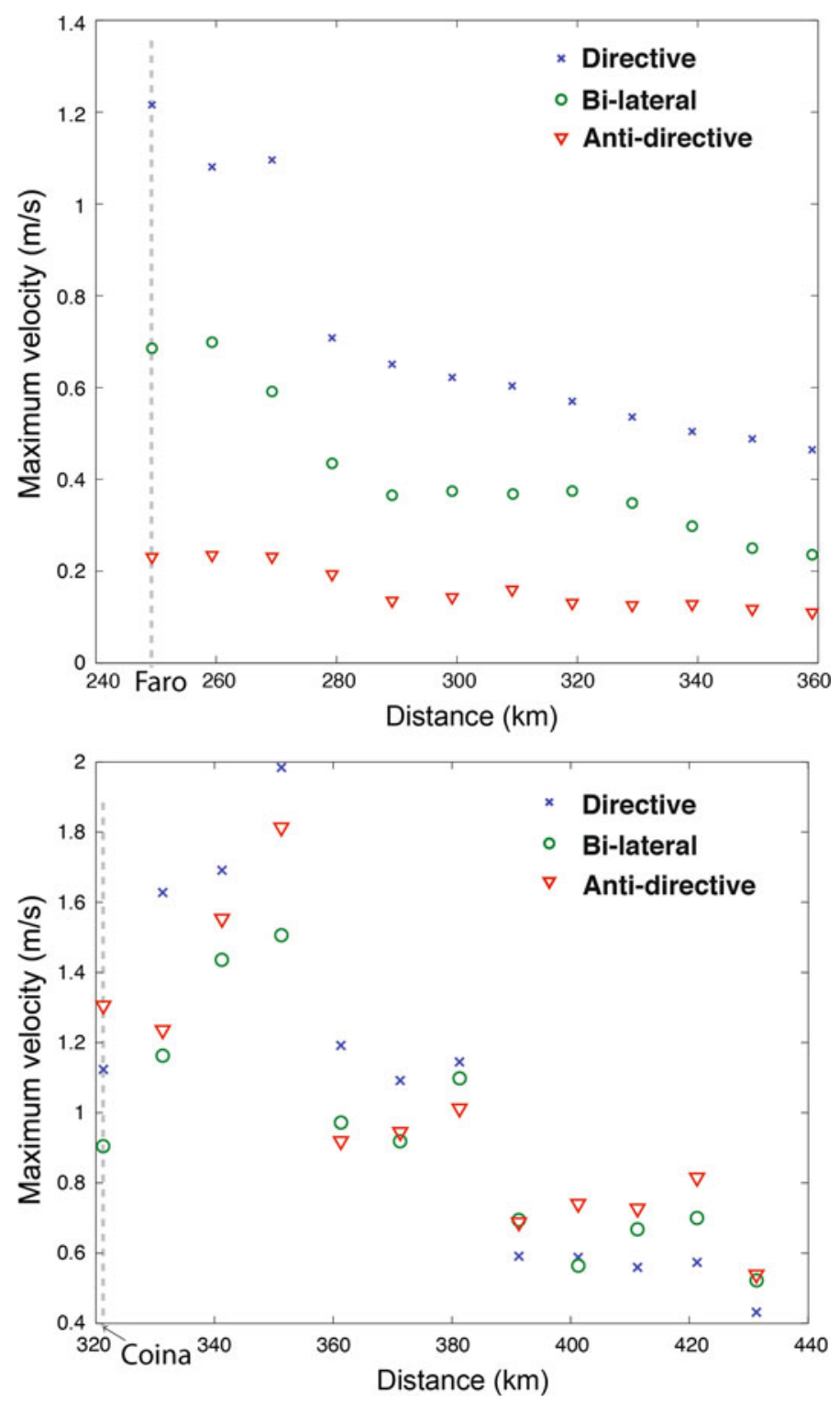

Fig. 8 Rupture directivity effect. Comparison of simulated maximum velocities obtained using a 3-D velocity model for the three proposed rupture scenarios: directive, bi-lateral and anti-directive for Faro (top) and Coina (bottom) profiles

earthquake (Somerville 2003). These moderate-to-long period pulses have been recognised to generate, on average, systematically larger responses in moderate-to-long period structures compared with responses induced by more typical 'rumbling' ground motions of similar severity. The latter ground motions are more common both at sites that are located close to the causative fault but in the backward directivity region and at sites that are far away from the rupture. 


\subsubsection{Earth structure (i.e. 3-D model)}

The second result shows the importance of structure for the calculation of ground motion. We show that the use of a stratified 1-D model is absolutely incorrect in SW Iberia and that the crustal structure varies dramatically along the ray paths, with large-scale heterogeneities of low or high velocities. The amplitude of ground motion, which has been shown to be strongly dependent on structure, was correctly calculated for most sites, including for distant locations. The 3-D velocity model used here provides a reasonable representation of the structure of the crust in SW Iberia. This model, however, should be considered a background model that requires improvement, particularly the addition of more information on near-surface velocity structure such as sedimentary basins. This work is in progress for the Lower Tagus Valley (LTB, Lisbon area) and is performed by the integration of information provided by a large number of commercial boreholes and seismic soundings made during the 1980s. With better resolution, this model will contribute to a better evaluation of the seismic hazard and risk in the LTB. In addition to this seismological contribution, high-resolution structure will be utilised to a greater degree, contributing to an understanding of the sedimentary and tectonic evolution of the Mesozoic Lusitanian and Cenozoic Lower Tagus Basins.

\subsection{Earthquake rupture behaviour and tsunami generation}

Based on a study of large and moderate shallow earthquakes $\left(M_{w} \geq 7.0\right)$, McGuire et al. (2002) showed that the majority of these earthquakes have a predominantly unilateral rupture. This observation quantifies what appears to be a general property of large earthquake dynamics. The unilateral character determined for the $M_{w} 9.3$ and 8.7 Sumatra earthquakes (Bezzeghoud et al. 2005) and for the $M_{w} 8.51755$ Lisbon earthquake (Grandin et al. 2007b) supports the observation made by McGuire et al. (2002) that ruptures are predominantly unilateral. However, the recent $M_{w} 8.8$ Maule (Chile) earthquake of 27 February 2008, characterised by a bilateral rupture (Madariaga et al. 2010), contradicts this observation. Furthermore, numerous studies of extended-source earthquake models examining the spatial and temporal evolution of earthquake slip on fault planes have shown that slips are spatially variable, and $48 \%$ of events nucleate in the regions of low slip (Mai et al. 2005). This behaviour was also observed for the 2004 and 2005 Sumatra earthquakes (Bezzeghoud et al. 2005) and the recent Maule (Chile) earthquake (Madariaga et al. 2010).

Most great tsunamigenic earthquakes are related to well-defined interplate convergence zones, such as the circum-Pacific seismic belt, the Sunda arc, the Hellenic arc or the Antilles arc. One exception is the massive earthquake that struck Iberia and Morocco on 1 November $1755\left(M_{w}=8.5-8.7\right)$, which was felt throughout a large part of Europe and produced a powerful tsunami that crossed the Atlantic Ocean. Many hypotheses have been proposed by various authors regarding the earthquake's location (Grandin et al. 2007b). However, a fault located below Gorringe Bank, with a rupture directed towards the SW, better reproduces the overall pattern of macroseismic observations than a fault aligned along the Marquês de Pombal-Pereira de Sousa Fault zone or a subduction-related thrust fault in the Gulf of Cádiz (Grandin et al. 2007b). This earthquake probably released as much or more energy as any seismic event in recorded history prior to December 2004. The Azores-Gibraltar fracture zone (AGFZ), which marks the boundary of active tectonic interaction between the African and Eurasian plates, is an active seismic region where large earthquakes occur frequently. Some of these earthquakes, particularly those near the eastern segment of this boundary, are capable of generating tsunamis. The tectonic 
interactions of the eastern segment of the AGFZ involve a thrusting component in the NW direction along a NE-trending strike plane (Buforn et al. 2004; Grandin et al. 2007b; Bezzeghoud et al. 2008). Observations from the mega $\left(M_{w} 9.3\right)$ earthquake of December 2004 in Sumatra and the $M_{w} 8.8$ Maule (Chile) earthquake offer new insights concerning rupture and tsunami generation in great subduction earthquakes, which may be applicable to the study of the 1755 earthquake and tsunami. The earthquake of 1755 generated a tsunami with waves about $6 \mathrm{~m}$ high at Lisbon, $15 \mathrm{~m}$ high along the coast of the Algarve and $20 \mathrm{~m}$ high at Cadiz, Spain. The waves travelled on to Martinique, a distance of $6,100 \mathrm{~km}$, in $10 \mathrm{~h}$ and there rose to a height of $4 \mathrm{~m}$. For the Sumatra mega earthquake, the waves may have been $15-30 \mathrm{~m}$ high along the entire 100-km stretch of coast from Kreung Sabe to the northwestern part of the island (USGS).

We conclude that it is very important, particularly in seismic risk studies, to take into account the rupture directivity and 3-D velocity model. These measures will provide encouraging results for the computation of low-frequency seismograms in the region and can be used to study larger earthquakes, for which the radiated wave field has a predominant low-frequency spectrum.

Acknowledgments This work has been developed with the support of the 'Fundação para a Ciência e a Tecnologia (FCT)' (Science and Technology Foundation) of the 'Ministério da Ciência, Tecnologia e do Ensino Superior (MCTES)', through the projects Topo-Med (TOPOEUROPE/0001/2007), SISMOD/LISMOT (PTDC/CTE-GIN/82704/2006) and WILAS (PTDC/CTE-GIX/097946/2008). The authors acknowledge helpful reviews of anonymous reviewers.

\section{References}

Abrantes F, Lebreiro S, Rodrigues T, Gil I, Bartels-Jónsdóttir H, Oliveira P, Kissel C, Grimalt JO (2005) Shallow-marine sediment cores record climate variability and earthquake activity off Lisbon (Portugal) for the last 2000 years. Quat Sci Rev 24:2477-2494

Alves TM, Gawthorpe RL, Hunt DW, Monteiro JH (2003) Cenozoic tectonosedimentary evolution of the Western Iberian Margin. Mar Geol 195:75-108

Andeweg B, De Vicente G, Cloetingh S, Giner J, Muñoz Martin A (1999) Local stress fields and intraplate deformation of Iberia: variations in spatial and temporal interplay of regional stress sources. Tectonophysics 305:153-164

Andrade C (1992) Tsunami generated forms in the Algarve barrier islands (south Portugal). Sci Tsunami Hazards 10(1):21-34

Argus DF, Gordon RG, DeMets C, Stein S (1989) Closure of the Africa-Eurasia-North America plate motion circuit and tectonics of the Gloria fault. J Geophys Res 94:5585-5602

Baptista MA, Miranda PMA, Chierici F, Zitellini N (2003) New study of the 1755 earthquake source based on multi-channel seismic survey data and tsunami modeling. Nat Hazards Earth Sci Syst 3:333-340

Baptista MA, Miranda JM, Luis JF (2006) In search of the 31 March 1761 earthquake and tsunami source. Bull Seismol Soc Am 96(2):713-721

Baptista MA, Miranda JM, Lopes FC, Joaquim FL (2007) The source of the 1722 Algarve earthquake: evidence from MCS and tsunami data. J Seismol 11:371-380

Barkan US, Brink T, Lin J (2009) Far field tsunami simulations of the 1755 Lisbon earthquake: implications for tsunami hazard to US East Coast and the Caribbean. Mar Geol 264(2009):109-122

Ben-Menahem A (1961) Radiation of seismic surface waves from finite moving sources. Bull Seismol Soc Am 51:401-435

Bezzeghoud M, Borges JF, Caldeira B (2005) The 2004 and 2005 Sumatra earthquakes. Implications for the Lisbon earthquake. In: 250th anniversary of the 1755 Lisbon Earthquake. International conference, 1-4 November 2005, Lisbon, Portugal, pp 592-598

Bezzeghoud M, Borges JF, Caldeira B, Buforn E, Udias A (2008) Seismic activity in the Azores Region in the context of the western part of the Eurasia-Nubia plate boundary. In: International seminar on seismic risk and rehabilitation on the 10th anniversary of the July 91998 Azores Earthquake, HortaAzores, 9-13 July, pp 27-31 
Bird P (2003) An updated digital model of plate boundaries. Geochem Geophys Geosyst 4(3):1027. doi: 10.1029/2001GC000252, ftp://element.ess.ucla.edu/PB2002/

Borges JF, Fitas AJS, Bezzeghoud M, Teves-Costa P (2001) Seismotectonics of Portugal and its adjacent Atlantic area. Tectonophysics 337:373-387

Borges JF, Bezzeghoud M, Buforn E, Pro C, Fitas A (2007) The 1980, 1997 and 1998 Azores earthquakes and its seismotectonic implications. Tectonophysics 435:37-54

Borges JF, M Bezzeghoud, B Caldeira, E Buforn (2008) Recent seismic activity in the Azores region. In: International seminar on seismic risk and rehabilitation on the 10th anniversary of the July 91998 Azores Earthquake, Horta-Azores, 9-13 July, pp 33-37

Brune JN (1970) Tectonic stress and spectra of seismic shear waves. J Geophys Res 75:4997-5009

Buforn E, Udías A, Colombás MA (1988) Seismicity, source mechanisms and seismotectonics of the Azores-Gibraltar plate boundary. Tectonophysics 152:89-118

Buforn E, Bezzeghoud M, Udías A, Pro C (2004) Seismic sources on the Iberia-African plate boundary and their tectonic implications. Pure Appl Geophys 161

Buforn E, Udías A, Martín Dávila J (2007) Source mechanism of the February 12, 2007, San Vicente Cape earthquake $\mathrm{M}_{\mathrm{w}}=5.9$, Orfeus Newsletter, 7, No. 2

Caldeira B, Bezzeghoud M, Borges JF (2009) DIRDOP: a directivity approach to determining the seismic rupture velocity vector. J Seismol, in open access. doi:10.1007/s10950-009-9183-X

Calvert A, Sandvol E, Seber D, Barazangi M, Roecker S, Mourabit T, Vidal F, Alguacil G, Jabour N (2000) Geodynamic evolution of the lithosphere and upper mantle beneath the Alboran region of the western Mediterranean: constraints from travel time tomography. J Geophys Res 105:10871-10898

Carrilho F, Teves-Costa P, Morais I, Pagarete J, Dias R (2004) Geoalgar Project—first results on seismicity and fault-plane solutions. Pure Appl Geophys 161(3):589-606

Chen WP, Grimison N (1989) Earthquakes associated with diffuse zones of deformation in the oceanic lithosphere: some examples. Tectonophysics 166:133-150

Chester DK, Chester OK (2010) The impact of eighteenth century earthquakes on the Algarve region, southern Portugal. Geogr J 176(4):350-370. doi:10.1111/j.1475-4959.2010.00367.x2

Dawson AG, Hindson R, Andrade C, Freitas C, Parish R, Bateman M (1995) Tsunami sedimentation associated with the Lisbon earthquake of 1 November AD 1755: Boca do Rio, Algarve, Portugal. Holocene 5(2):209-215

DeMets C, Gordon RG, Argus DF, Stein S (1994) Effect of recent revisions to the geomagnetic reversal time scale and estimates of current plate motions. Geophys Res Lett 21:2191-2194

Fadil A, Vernant P, McClusky S, Reilinger R, Gomez F, Ben Sari D, Mourabit T, Feigl K, Barazangi M (2006) Active tectonics of the western Mediterranean: geodetic evidence for rollback of a delaminated subcontinental lithospheric slab beneath the Rif Mountains, Morocco. Geology 34(7):529-532

Gràcia E, Dañobeitia J, Vergés J, Bartolomé R, Córdoba D (2003) Crustal architecture and tectonic evolution of the Gulf of Cadiz (SW Iberian margin) at the convergence of the Eurasian and African plates. Tectonics 22(4):1033. doi:10.1029/2001TC901045

Grandin R, Borges JF, Bezzeghoud M, Caldeira B, Carrilho F (2007a) Simulations of strong ground motion in SW Iberia for the 1969 February $28(\mathrm{MS}=8.0)$ and the 1755 November $1(\mathrm{M} \sim 8.5)$ earthquakes-I. Velocity model. Geophys J Int 171(3):1144-1161

Grandin R, Borges JF, Bezzeghoud M, Caldeira B, Carrilho F (2007b) Simulations of strong ground motion in SW Iberia for the 1969 February $28(\mathrm{MS}=8.0)$ and the 1755 November $1(\mathrm{M} \sim 8.5)$ earthquakes-II. Strong ground motion simulations. Geophys J Int 171(2):807-822

Gutscher MA, Malod J, Rehault JP, Contrucci I, Klingelhoefer F, Mendes-Victor L, Spackman W (2002) Evidence for active subduction beneath Gibraltar. Geology 30:1071-1074

Gutscher M-A, Baptista MA, Miranda JM (2006) The Gibraltar Arc seismogenic zone. Part 2: constraints on a shallow east dipping fault plane source for the 1755 Lisbon earthquake provided by tsunami modeling and seismic intensity. Tectonophysics 426(1-2):153-166

Hartzell S et al (2006) Modeling and validation of a 3D velocity structure for the Santa ClaraValley, California, for seismic-wave simulations. Bull Seismol Soc Am 96(5):1851-1881

Jiménez-Munt I, Fernàndez M, Torne M, Bird P (2001) The transition from linear to diffuse plate boundary in the Azores-Gibraltar region: results from a thin-sheet model. Earth Planet Sci Lett 192:175-189

Johnston A (1996) Seismic moment assessment of earthquakes in stable continental regions-III. New Madrid 1811-1812, Charleston 1886 and Lisbon 1755. Geophys J Int 126:314-344

Kagawa T, Zhao B, Miyakoshi K, Irikura K (2004) Modeling of 3D basin structures for seismic wave simulations based on available information on the target area: case study of the Osaka Basin, Japan. Bull Seismol Soc Am 94:1353-1368

Larsen SC, Schultz CA (1995) ELAS3D, 2D/3D elastic finite- difference wave propagation code, Lawrence Livermore National Laboratory, UCRLMA-121792, 18 p 
Larsen S, Antolik M, Dreger D, Stidham C, Schultz C, Lomax A, Romanowicz B (1997) 3D models of seismic wave propagation; simulating scenario earthquakes along the Hayward Fault. Seismol Res Lett $68(2): 328$

Levret A (1991) The effects of the November 1st, 1755 "Lisbon" earthquake in Morocco. Tectonophysics 193:83-94

LNEC (1986) A Sismicidade Histórica e a Revisão do Catálogo Sísmico. Laboratório Nacional de Engenharia Civil (LNEC)

Lynnes CS, Ruff LJ (1985) Source process and tectonic implications of the great 1975 North Atlantic earthquake. Geophys J R Astron Soc 82:497-510

Machado F (1966) Contribuição para o estudo do terremoto do terramoto de 1 de Novembro de 1755, Rev. Fac. Ciências, Lisboa, C14, 19-31

Madariaga R (1976) Dynamics of an expanding circular fault. Bull Seismol Soc Am 66(3):639-666

Madariaga R, Vigny Ch, Lancieri M, Ruiz S, Métois M, Socquet A, Fuenzalida A, Buforn E, Campos J (2010) The $M_{w}=8.8$ Maule earthquake in Chile: a preliminary view. In: Silva AM, Reis AH, Fitas A, Figueiredo J, Caldeira B, Bezzeghoud M (eds) Jornadas de Física por ocasião da jubilação do Professor Rui Namorado Rosa. Universidade de Évora, Évora, pp 275-290. ISBN 978-989-95091-2-2

Mai PM, Spudich P, Boatwright J (2005) Hypocenter locations in finite-source rupture models. Bull Seismol Soc Am 95(3):965-980

Martínez-Solares JM, Lopez A, Mezcua J (1979) Isoseismal map of the 1755 Lisbon earthquake obtained from Spanish data. Tectonophysics 53:301-313

Matias LM (1996) A sismologia experimental na modelação da estrutura da crusta em Portugal continental, Ph.D. thesis. Univ. of Lisbon, 398 pp.

McClusky S, Reilinger R, Mahmoud S, Ben Sari D, Tealeb A (2003) GPS constraints on Africa (Nubia) and Arabia plate motions. Geophys J Int 155:126-138

McGuire JJ, Zhao L, Jordan TH (2002) Predominance of unilateral rupture for a global catalog of earthquakes. Bull Seismol Soc Am 92:3309-3317

Mendes-Victor L, Baptista MA, Miranda JM, Miranda PMA (1999) Can hydrodynamic modelling of tsunami contribute to seismic risk assessment? Phys Chem Earth 24:139-144

Moreira VS (1982) Sismotectónica de Portugal Continental e Região Atlântica adjacente. INMG, Lisboa (in Portuguese)

Moreira VS (1984) Sismicidade histórica de Portugal Continental, Revista do Instituto Nacional de Meteorologia e Geofísica, Lisbon, (in Portuguese)

Moreira VS (1985) Seismotectonics of Portugal and its adjacent area in the Atlantic. Tectonophysics 11:85-96

Olsen KB, Archuleta RJ (1996) Site response in the Los Angeles Basin from 3-D simulations of ground motion. SRL 67(2):49

Pereira de Sousa FL (1919) O terremoto do 1 de Novembro de 1755 em Portugal e um estudo demográfico (Serviços Geológicos de Portugal), vol I-IV (in Portuguese)

Pitarka A, Graves R, Sommerville P (2004) Validation of a 3D velocity model of the Puget Sound region based on modeling ground motion from the 28 February 2001 Nisqually earthquake. Bull Seismol Soc Am 94(5):1670-1689

Reid HF (1914) The Lisbon earthquake of November 1, 1755. Bull Seismol Soc Am 4(2):53-80

Ribeiro A (2002) Soft plate and impact tectonics, Springer, $324 \mathrm{p}$

Ribeiro A, Cabral J, Baptista R, Matias L (1996) Stress pattern in Portugal mainland and the adjacent Atlantic region, West Iberia. Tectonics 15:641-659

Scheffers A, Kelletat D (2005) Tsunami relics on the coastal landscape west of Lisbon, Portugal. Sci Tsunami Hazards 23(1):3-16

Somerville PG (2003) Magnitude scaling of the near fault rupture directivity pulse. Phys Earth Planet Int 137:201-207

Stich D, Ammon CJ, Morales J (2003) Moment tensor solutions for small and moderate earthquakes in the Ibero-Maghreb region. J Geophys Res 108:2148

Terrinha PAG (1998) Structural geology and tectonic evolution of the Algarve basin, South Portugal. PhD thesis, Royal School of Mines, Imperial College, London, $423 \mathrm{pp}$

Terrinha P, Pinheiro LM, Henriet J-P, Matias L, Ivanov MK, Monteiro JH, Akhmetzhanov A, Volkonskaya A, Cunha T, Shaskin P, Rovere M (2003) Tsunamigenic-seismogenic structures, neotectonics, sedimentary processes and slope instability on the southwest Portuguese Margin. Mar Geol 195:55-73

Teves-Costa P, Borges JF, Rio I, Ribeiro R, Marreiros C (1999) Source parameters of old earthquakes: semiautomatic digitalization of analog records and seismic moment assessment. Nat Hazards 19:205-220

Thiebot E, Gutscher M-A (2006) The Gibraltar Arc seismogenic zone (part 1): constraints on a shallow east dipping fault plane source for the 1755 Lisbon earthquake provided by seismic data, gravity and 
thermal modeling. Tectonophys Sp Vol "Nat Lab Seismogenic Faults" 427:135-152. doi: 10.1016/j.tecto.2006.02.024

Udias A, Buforn E (1994) Seismotectonics of the Mediterranean region. Adv Geophys 36:121-209

Udías A, López Arroyo A, Mézcua J (1976) Seismotectonics of the Azores-Alboran region. Tectonophysics 31:259-289

Vilanova SP (2003) Sismicidade e Perigosidade Sísmica do Vale Inferior do Tejo. Ph.D. thesis, University of Lisbon, $259 \mathrm{pp}$

Watson DF (1982) Automatic contouring of raw data, computers and geosciences. Pergamon Press Ltd., 1, $8,97-101$

Wilson JT (1966) Did the Atlantic close and then re-open? Nature 211:676-681

Zitellini $\mathrm{N}$ et al (2001) Source of the 1755 Lisbon earthquake and tsunami investigated. EOS Trans Am Geophys U 82:285

Zitellini N, Gràcia E, Matias L, Terrinha P, Abreu MA, DeAlteriis G, Henriet JP, Dañobeitia JJ, Masson DG, Mulder T, Ramella R, Somoza L, Diez S (2009) The quest for the Africa-Eurasia plate boundary west of the Strait of Gibraltar. Earth Planet Sci Lett 280:13-50 